\title{
Effects of site preparation with micro-basins on Pinus halepensis Mill. afforestations in a semiarid ombroclimate
}

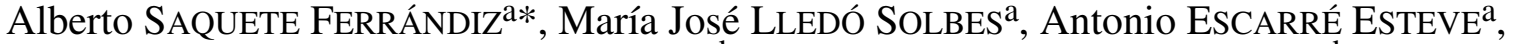 \\ María Angeles RIPOLl MORALES ${ }^{b}$, Estanislao DE-SimÓn NAVARRETE ${ }^{b}$ \\ a Department of Ecology, University of Alicante, Ap. 99, 03080 Alicante, Spain \\ b CIFA (Centro de Investigación y Formación Agraria), Ap. 2027, 18080 Granada, Spain
}

(Received 8 July 2004; accepted 29 September 2005)

\begin{abstract}
A forested area at the Sierra de Gador, Almería, Spain, was afforested with Aleppo pine (Pinus halepensis Mill.) 13 years ago using a technique never before used in Europe for forested areas: banks with micro-basins. This technique is compared in our study to the banks without micro-basins, both in sunny and shady slopes. It is also analysed whether this site preparation modifies the specific composition of the pre-existing vegetation. The average height of the pines planted on shady plots with micro-basins is $3.06 \mathrm{~m}$ whereas in shady plots without micro-basins the average height is $2.37 \mathrm{~m}$, in sunny slope average height are $2.52 \mathrm{~m}$ compared to $1.61 \mathrm{~m}$ with and without micro-basins. These differences are significant, as are the ones in diameter: $11.1 \mathrm{~cm}$ compared to $8.5 \mathrm{~cm}$ in the first case and 11.0 compared to $7.0 \mathrm{~cm}$ in the second. Micro-basins supply possibly enough water to the banks so that the annual increase of the growth rings does not depend on the rainfall, not even during a particularly dry year. In plots without micro-basins there is a close relationship between the annual trunk growth and the spring rainfall. Using a multivariate analysis it is shown that neither land removal or a change in the hydric accumulations affect the composition of the preexisting vegetation.
\end{abstract}

micro-basins / site preparation / semiarid / Pinus halepensis / soil compensation

Résumé - Effets de la préparation du terrain sur des micro-bassins dans des reboisements de Pinus halepensis Miller en conditions de climat semi-aride. Un reboisement avec du pin d'Alep a été réalisé en 1988 dans une région forestière de la chaîne de montagnes espagnole de Gâdor, Almeria. Cette opération a utilisé pour la première fois en Europe la technique de « la banquette de micro-bassins ». On peut comparer l'effet de cette technique avec celle des banquettes sans micro-bassins à l'adret ou à l'ubac de vallées sur la croissance des pins et sur la composition spécifique de la végétation. La hauteur moyenne des pins des parcelles à l'ubac était de 3,06 $\mathrm{m}$ avec microbassins et de 2,37 $\mathrm{m}$ sans micro-bassins. Dans les parcelles à l'adret, la hauteur moyenne était respectivement de 2,52 et de 1,61 m. Les différences sont également significatives pour les diamètres à l'ubac, soit $11,1 \mathrm{~cm}$ contre $8,5 \mathrm{~cm}$ respectivement avec et sans microbassins, et à l'adret $11,0 \mathrm{contre} 7,0 \mathrm{~cm}$. Les micro-bassins fournissent l'eau nécessaire à la banquette pour que la croissance annuelle des arbres ne soit pas dépendante des précipitations, même lors d'une année sèche. En revanche, il existe une corrélation entre l'accroissement annuel du tronc et les précipitations du printemps dans les parcelles sans micro-bassins. Les analyses multifactorielles ont montré que ni le terrassement ni le changement des flux hydriques ne modifient la composition spécifique de la végétation.

micro-bassins / préparation du terrain / semi-aride / Pinus halepensis / compensation du sol

\section{INTRODUCTION}

Different authors, [7, 11, 23] have underlined the importance of climatic conditions operating on the tree seedlings during the first year of planting on the land. Fernández et al. [13] indicate as well that environmental conditions affect survival and growth in forest plantations. On the other hand, Poret et al. [20] point out that the highest rate of seedling mortality takes place during the first summer, and South et al. [32] strengthen the positive influence exerted by the site preparation at the planting stage.

The main limiting factor in the Mediterranean climate is the lack of water, especially during the summer months $[3,10,19$,
29]. This is the reason why the introduction of seedlings linked to the site preparation focused on concentrating runoff water on the seedling bed can not only improve the afforestation and avoid its failure [2,9] but also increase the afforestation growth $[12,30]$.

This article aims to compare the long-term effects of two different types of site preparations: banks and banks with microbasins. The latter technique was used by De Simón et al. in 1984 in afforestations done in semiarid areas by the Forest Service of the General Directorate of the IARA (Andalusian Institute for Agriculture Reform) in Almeria, Spain. This technique concentrates water on the banks and increases soil moisture in the afforestation area [8]. This soil compensation [6, 24] counteracts

\footnotetext{
* Corresponding author: Alberto.Saquete@ua.es
} 


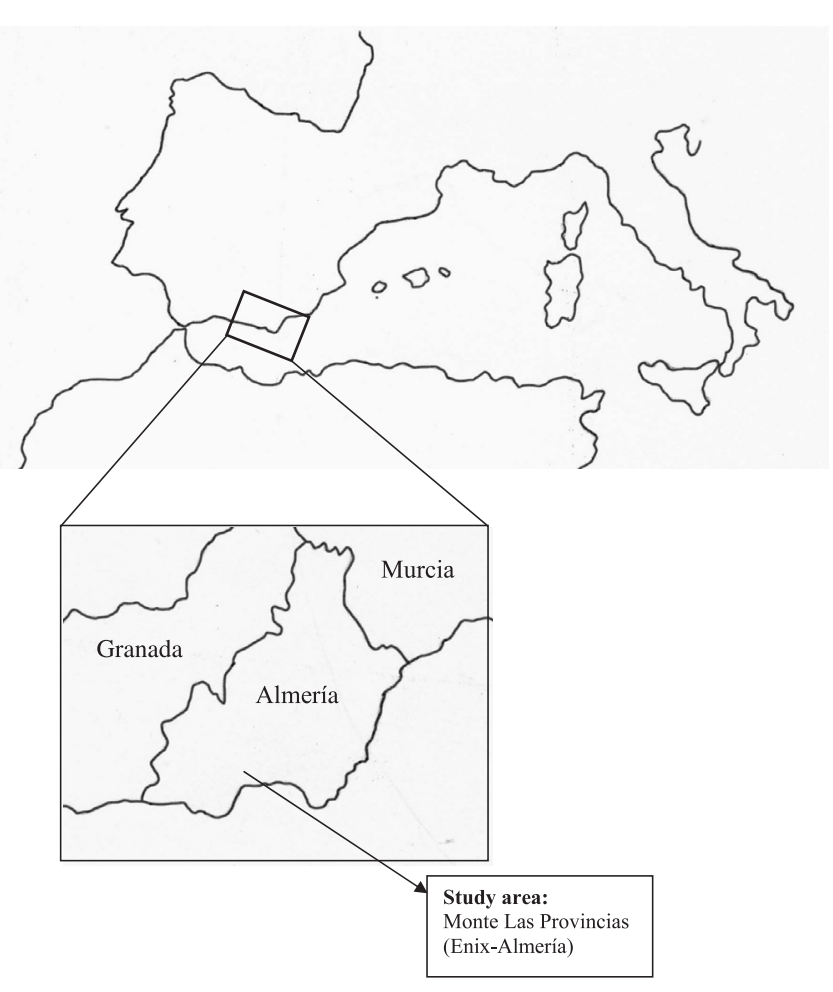

Figure 1. Study area located in Monte Las Provincias (Enix-Almería, Spain).

the lack of water during the drought periods characteristic of semiarid Mediterranean areas [27, 34]. Furthermore, two different orientations are studied: sunny and shady slopes, so that using all the possible combinations four different groups are identified.

Site preparation must be directed not only to concentrate runoff water and to improve infiltration where needed but also to increase the volume of the soil in the parts where the roots are developed $[14,27,29]$ and to avoid the alteration of vegetation, as it protects from erosion and improves the seedling planting $[5,35]$. The soil preparation must be also appropriate to preserve the area biodiversity $[18,25]$. Due to these specifications, the second part of this study is partly devoted to analyse the influence exerted by both techniques on the pre-existing vegetation.

Dimensions, both of the banks and of the micro-basins, must be linked to the climatic characteristics of the area so that enough water is supplied with the normal rainfall $[23,25]$ and so that they can handle a cloudburst originating a great runoff $[1,21]$. On the other hand, the banks must have overflow channels to avoid the flooding of the afforestation area, as well as channels to lead the surplus water from the hillside to natural runways [2,9], so avoiding the banks destabilisation.

Follow-up studies on afforestations usually cover the first two to three years after the trees are planted [4, 28]. In this article we will analyse the biometric characteristics of Pinus halepensis planted 13 years ago. Also, in this afforestation it was the first time that the technique of micro-basins linked with

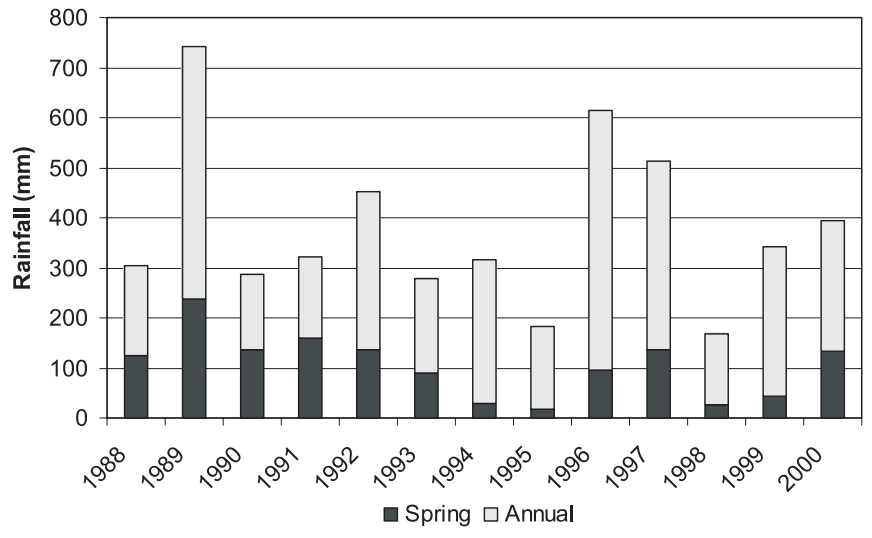

Figure 2. Annual rainfall (dotted bar) and spring rainfall (solid bar) for the years during which the trees have been on the site, in $\mathrm{mm}$ of water.

banks aimed to concentrate water was used. This is very important in semiarid climates as the one we are dealing with.

\section{MATERIALS AND METHODS}

\subsection{Study area}

This study was carried out in the mountain known as Monte "Las Provincias", belonging to the Junta de Andalucía [Andalusian Regional Government], located on the South side of the Sierra de Gador, in the municipal area of Enix, part of the Almerian Alpujarras (Fig. 1). The location is approximately $10 \mathrm{~km}$ to the sea, the height is $800 \mathrm{~m}$ above sea-level and it has a very thermic inferior dry climate (a mean annual temperature of $17^{\circ} \mathrm{C}$ ). Both sunny and shady slopes, well identifiable and with slopes ranging from $30 \%$ to $55 \%$, can be found in the area.

As shown in Figure 2, rainfall changes considerably throughout the years and even if the average rainfall is $378 \pm 43.61 \mathrm{~mm}$ of water, only in two years rainfall gets close to such figure. During the other years rainfall fluctuates between $168 \mathrm{~mm}$ and $741 \mathrm{~mm}$. The darkest part of the columns (Fig. 2) shows the spring rainfall, which also changes considerably. While the average spring rainfall is $105.35 \pm 17.62 \mathrm{~mm}$, there was only $17.5 \mathrm{~mm}$ during the driest spring and of $238 \mathrm{~mm}$ during the wettest.

Vegetation in the study area consists mainly of characteristic species of the Mediterranean shrubland, such as Stipa tenacissima L., Cistus albidus L., Ulex parvifllorus Pourret, Brachypodium retusum (Pers.) Beauv., Rosmarinus officinalis L., different species of Thymus sp. and Teucrium sp., as well as a few Quercus coccifera L. and Rhamnus lycioides $\mathrm{L}$. The average vegetation cover in the area is $80 \%$ of the land and is never below $50 \%$.

\subsection{Experimental design}

In 1988 the Andalusian Regional Government carried out several afforestations on different sidehills of the mountain known as "Las Provincias" with seedlings of Aleppo pine (Pinus halepensis Mill.), coming near the studied area to avoid differences in the growth due to genetic characteristics of the individuals [13]. Site preparation consisted of banks $80 \times 40 \mathrm{~cm}$ in surface and $40 \mathrm{~cm}$ in depth, dug with a pullshovel. In a half of them side channels oblique to the sidehill 


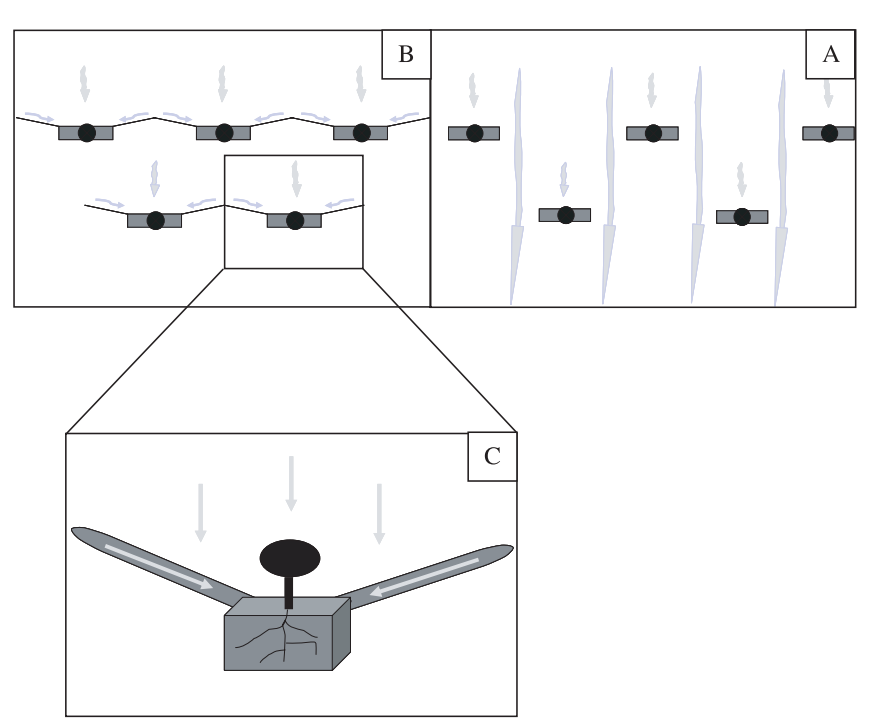

Figure 3. (A) Banks without micro-basins, (B) Banks with microbasins, both with its water runoff drew, and (C) Water flows details in a bank with micro-basins.

upstream and converging in the bank were carved. This site preparation is known as banks with micro-basins [8] (Fig. 3).

This simple design allows us to channel through the planting bank the total rainfall of a bigger land surface than which we would obtain without using this technique. The scarce resources existing in the peninsular Spain semiarid Mediterranean climate have been concentrated and allow the improvement of afforestation. It permits an increase both in growth and in the effects of soil protection [23].

Afforestation was made following a triangular planting pattern, with a density of 600 seedlings per hectare.

In January 2001 twelve plots of $20 \times 25 \mathrm{~m}$ in surface were identified, with a total of 30 banks into the plot. Three of them were allocated to every one of the following situations: exposure in sidehills (three in sunny slopes and three in shady slopes) and type of site preparation (three on normal banks and three on banks with micro-basins). Precisely, plots headed P1, P2 and P3 are banks with micro-basins in shady slopes, P4, P5 and P6 are banks with micro-basins in sunny slopes, P7, P8 and P9 are banks without micro-basins in shady slopes and P10, P11 and P12 are banks without micro-basins in sunny slopes. Every trees heights and basal diameters were measured in all plots. The basal diameter was used because it is the only measurable point in all cases without being interfered by the branches.

From the frequency distribution of diameter we chose two individuals for core sampling, one with a mean diameter and other with a high diameter. We extracted one core in each individual using a Pressler increment borer at $30 \mathrm{~cm}$ over the base as minimum height in order to extract the core in the correct way. We took the cores following a $\mathrm{N}-\mathrm{S}$ direction in order to have a better reading of rings since these are wider to the North position.

This data was used in order to correlate the yearly increment in thickness with the yearly rainfall. Nevertheless, due to the small number of trees in which the ring growth could be measured, the more reliable plot grouping is that in which we could use the diameter and height data of all the individuals as we previously described.

In order to study vegetation of the area, inventories of presenceabsence of species existing in every plot were made. All area has a specific list of species, in every plot the presence of each species is marked with 1 and its absence is marked with 0 . Combination in 0 and 1 of each plot will give us its relations, and we can identify the introduction of nitrophile and hydrophile species that could compete with pines or other pre-existent species.

\subsection{Measuring parameters}

Measures taken and instruments used were as follows:

- Total height of every individual tree from the base of the trunk to the apical eye was measured with a telescopic sight tapered in $\mathrm{cm}$.

- Basal diameter of the stem was measured at ground level with a calliper tapered in $\mathrm{mm}$.

- Tree-ring width was measured with a Lega Smil 3.3 measuring system on cores extracted with a Pressler increment borer. This measure was taken in $1 / 100 \mathrm{~mm}$.

In order to compare results, mean height, diameter and thickness of growth rings measures were taken in every plot, combining the three plots in every block to obtain a single result in every case. However, the twelve plots were individually compared in regards to the vegetation.

\subsection{Data analysis}

For the statistical comparison of data, mean values and dispersion measures of height, basal diameter and thickness of growth rings were used.

The package used for such analysis was Microsoft SPSS 10.0 for Windows. To compare the growth we entered the data of increment of each core and year in the statistics one-way ANOVA with a group comparison through a Tukey-b Test. This program processes the data using the arithmetic average of the thickness of the 13 rings of each tree to obtain a plot average and then be able to calculate the statistic significance. Statistics applied to height and diameter of the pines consisted in Kruskal-Wallis non-parametric tests for the total data and Mann Whitney's U for pairs of data, at a level of significance of 0.05 .

Two different statistical procedures were used to determine whether the use of different techniques of site preparation influenced the development of different types of vegetation. On the one hand, the specific composition of the twelve sampled plots was compared using a Multiple Correspondence Analysis using the CANOCO 4.0. package, which has been created to analyse the vegetation and it is capable to use the presence-absence parameter. With the residuals of this analysis using the Adobe Statistica 6.0. package, homogeneous groups were isolated and hierarchically arranged in a cluster analysis. First three coordinates factors of the multivariate analysis variables, which explain most of the variation found, were used for that purpose.

\section{RESULTS}

\subsection{Growth}

Both variables used in the analysis, height and basal diameter, were averaged for every one of the four groups in order to observe variation in parameters.

The highest pines are on the banks with micro-basins in shady slopes (Fig. 4A) whereas banks in sunny slopes have the smallest $(Z=-3.55 ; p<0.001)$ individuals compared statistically $(Z=-1.72 ; p=0.085)$ to the ones on the banks in shady slopes and the smallest statistical heights $(Z=-7.35 ; p<0.001)$ are those of individuals on banks in sunny slopes.

No significant differences in the basal diameter (Fig. 4B) were found between individuals on banks with micro-basins in sunny slopes and those on shady slopes $(Z=-0.432 ; p=0.666)$ 

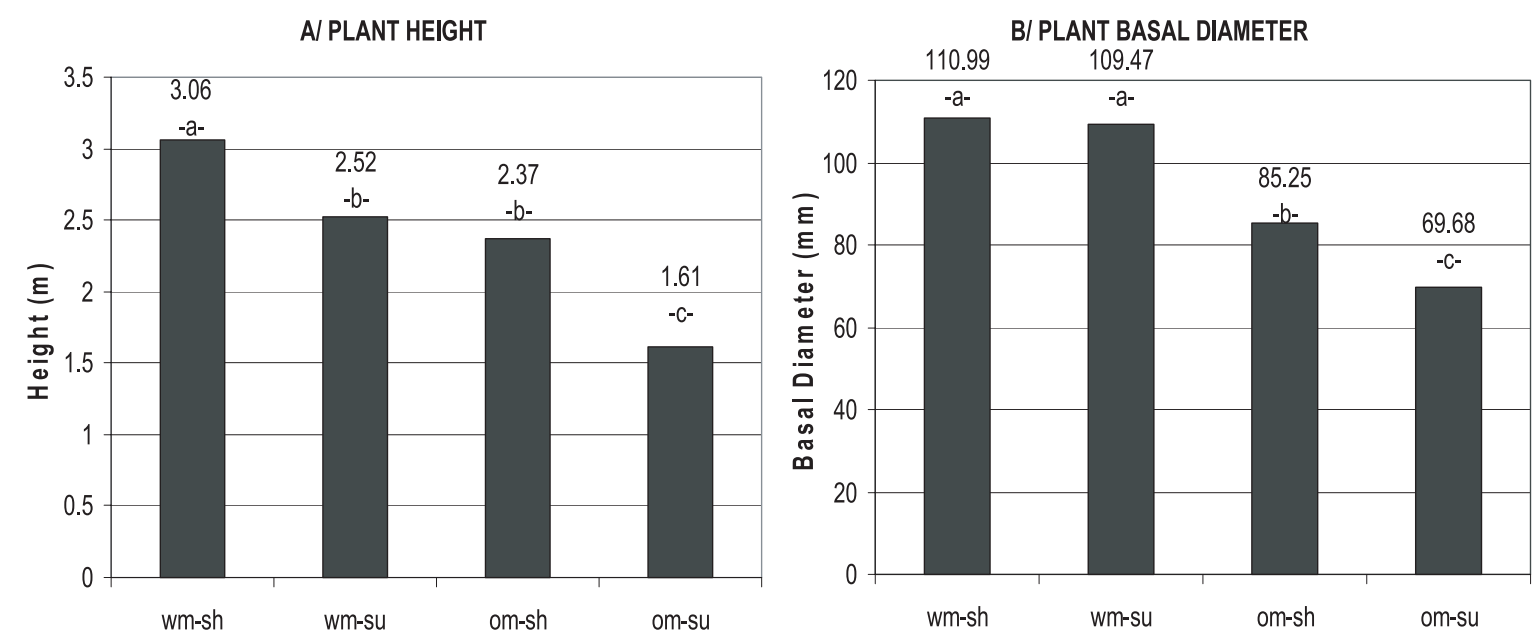

Figure 4. Average height $(\mathbf{A})$ and average basal diameter $(\mathbf{B})$ of the twelve sampled plots, grouped in the four identified environments with an indicative letter of statistical similarity or difference at the level of significance of 0.05 . The four environments being: banks with micro-basins in shady slopes (wm-sh), banks with micro-basins in sunny slopes (wm-su), banks without micro-basins in shady slopes (om-sh) and banks without micro-basins in sunny slopes (om-su).
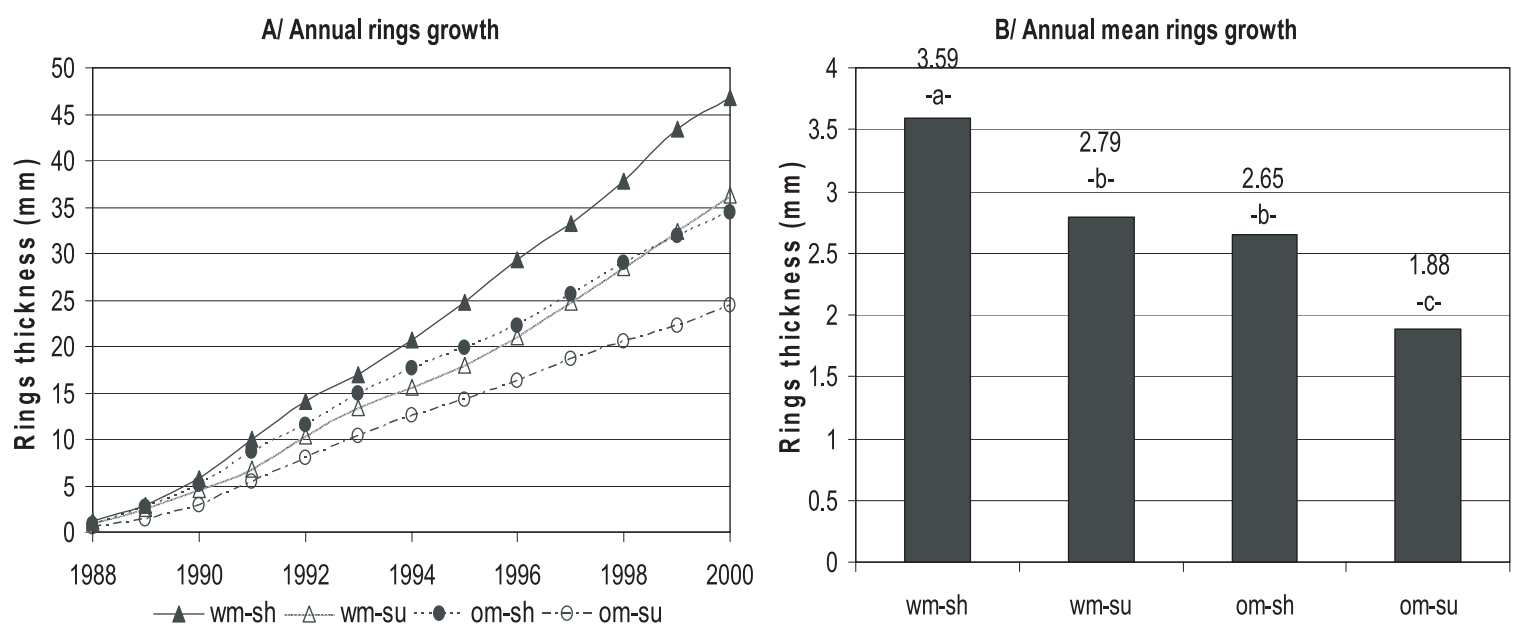

Figure 5. Cumulative mean thickness $(\mathbf{A})$ and annual mean ring growth $(\mathbf{B})$. In the latter case the statistical significance letters are at a level of significance of 0.05 . The four environments are: banks with micro-basins in shady slopes (wm-sh), banks with micro-basins in sunny slopes (wm-su), banks without micro-basins in shady slopes (om-sh) and banks without micro-basins in sunny slopes (om-su).

but there are significant differences in individuals located on banks without micro-basins, which have smaller diameters. As expected, banks without micro-basins where the basal diameters of individuals are bigger are the ones in shady slopes, whereas the smallest individuals are again those located in sunny slopes $(Z=-3.91 ; p<0.001)$.

\subsection{Growth rings}

Using the average measures of the six trees cored on every plot, we have represented the annual cumulative growth and the annual average ring growth (Figs. 5A and 5B respectively) the four groups follow a normal distribution, with values of ShapiroWilk statistics of $0.967,0.900,0.938$ and 0.908 with significa- tions of $0.881,0.161,0.567$ and 0.203 respectively in lots with micro-basins in sunny and shady slopes and for the lots without micro-basins in sunny and shady slopes.

In the figure showing the cumulative growth, we can see a graph with a steeper slopes in the block of trees located on banks with micro-basins in shady slopes $(\theta=3.91)$; likewise, ring growths are similar in trees located on banks in shady slopes and on banks with micro-basins in sunny slopes (similar slopes $\theta=2.86$ and 2.95 respectively); and the slopes that are not as steep represent the growth of pines planted on normal banks $(\theta=2.07)$. As far as the annual mean ring growth is concerned, we find the same relationship between the groups studied, with the statistical differences represented by letters in the figure, at a level of significance of 0.05 . The statistical value obtained is $F=11.797 ; p<0.001$. 

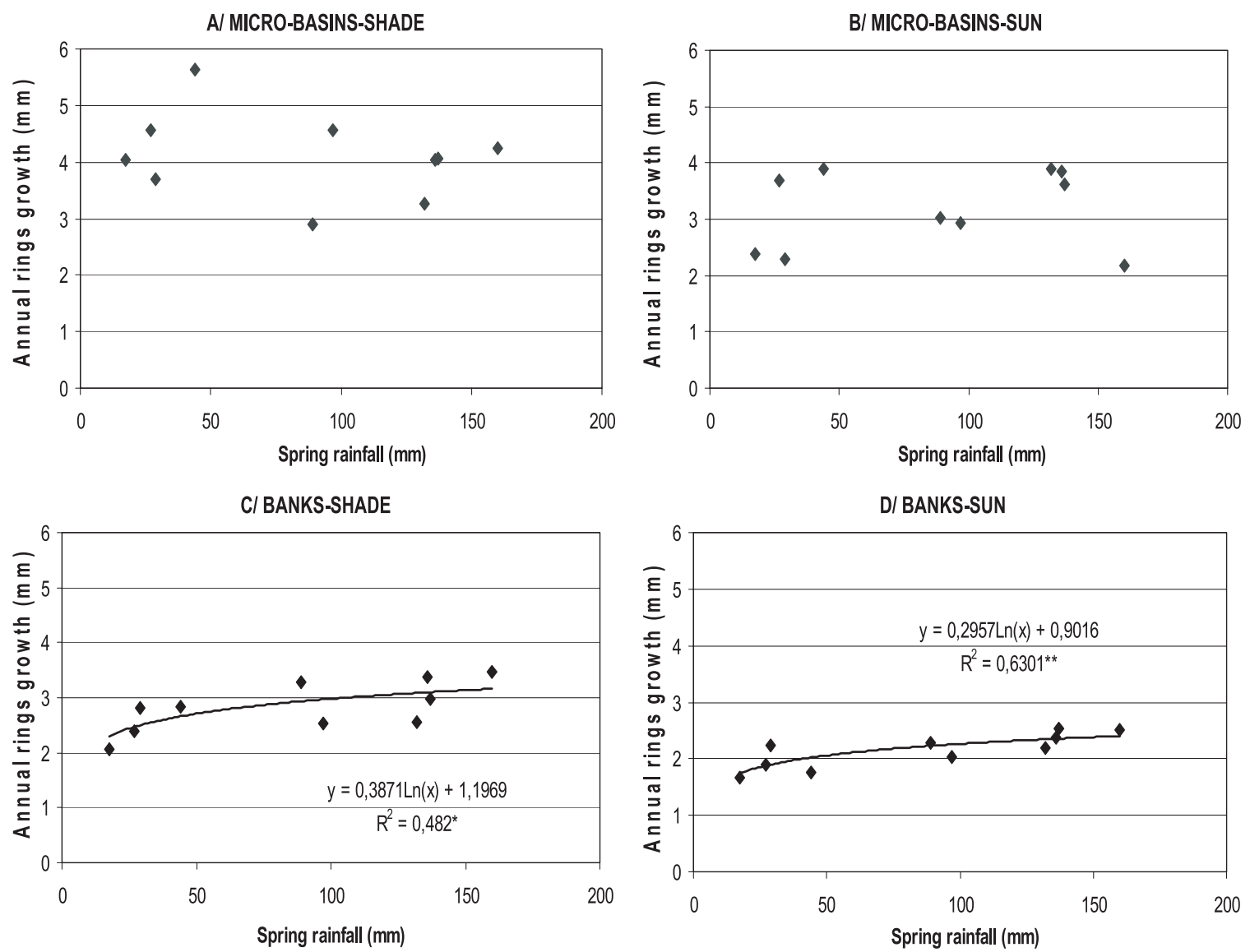

Figure 6. Annual mean ring growth compared to spring rainfall on that particular year, for the four environments on study: (A) banks with micro-basins in shady slopes (wm-sh), (B) banks with micro-basins in sunny slopes (wm-su), (C) banks without micro-basins in shady slopes (om-sh) and (D) banks without micro-basins in sunny slopes (om-su). In every case, both the adjusting equation and the regression coefficient $\left(R^{2}\right)$ are shown, including the statistical significance $* * *$ for $p<0.05$ and $p<0.01$. When there is no asterisk it means that there is no statistical significance.

We have studied the correlation existing between the annual and the seasonal rainfall and the annual trunk growth, and the only correlation shown is that of the rainfall values in the spring season, there is no correlation between the growth of the rings and the rainfall in any other season or the annual total. Figure 6 shows the relationship between these two variables; spring rainfall and ring growth on that particular year, with the exception of the first three years, when the growth is too small to be noticeable. We have to underline that the growth of individuals on the banks without micro-basins correlates with the spring rainfall, both in shady $p<0.05$ (Fig. 6C) and in sunny slopes $p<0.001$ (Fig. 6D). We can see how growth increases exponentially as rainfall increases, until reaching approximately 60 to $80 \mathrm{~mm}$, where the growth rings do not get any thicker.

If we observe Figures $6 \mathrm{~A}$ and $6 \mathrm{~B}$, corresponding to banks with micro-basins in shady and sunny slopes respectively, we can see that in any case the ring growth correlates significantly with rainfall. Therefore, the same amount of growth occurs both with a small and with a big rainfall; in the wide range of spring rainfall of the latest years there has been no interdependence of either.

\subsection{Vegetation}

If we observe the figures showing the distribution of the different plots along one of the analysis axis (Fig. 7) and the distribution of the homogeneous groups within the results (Fig. 8) we can see a clear difference between the plots located in sunny and shady slopes as far as the existence of different vegetal species is concerned. Therefore, plots in sunny slopes are statistically very close among themselves but very far from those in shady slopes, no matter what type of planting technique was used in the afforestation.

On the other hand, differences in vegetation in plots planted using normal banks and in those where banks with micro-basins on either orientation were made cannot be noticed as these plots are closely intermixed. That is to say, at least one of the plots meant to characterise one of the different types of planting techniques in such orientation is closer to the plots devoted to the other kind of planting technique than to its own group of plots.

Therefore, within the plots inventory we find species preferring a particular orientation and which only appear in that specific orientation, whereas some species appearing in one 


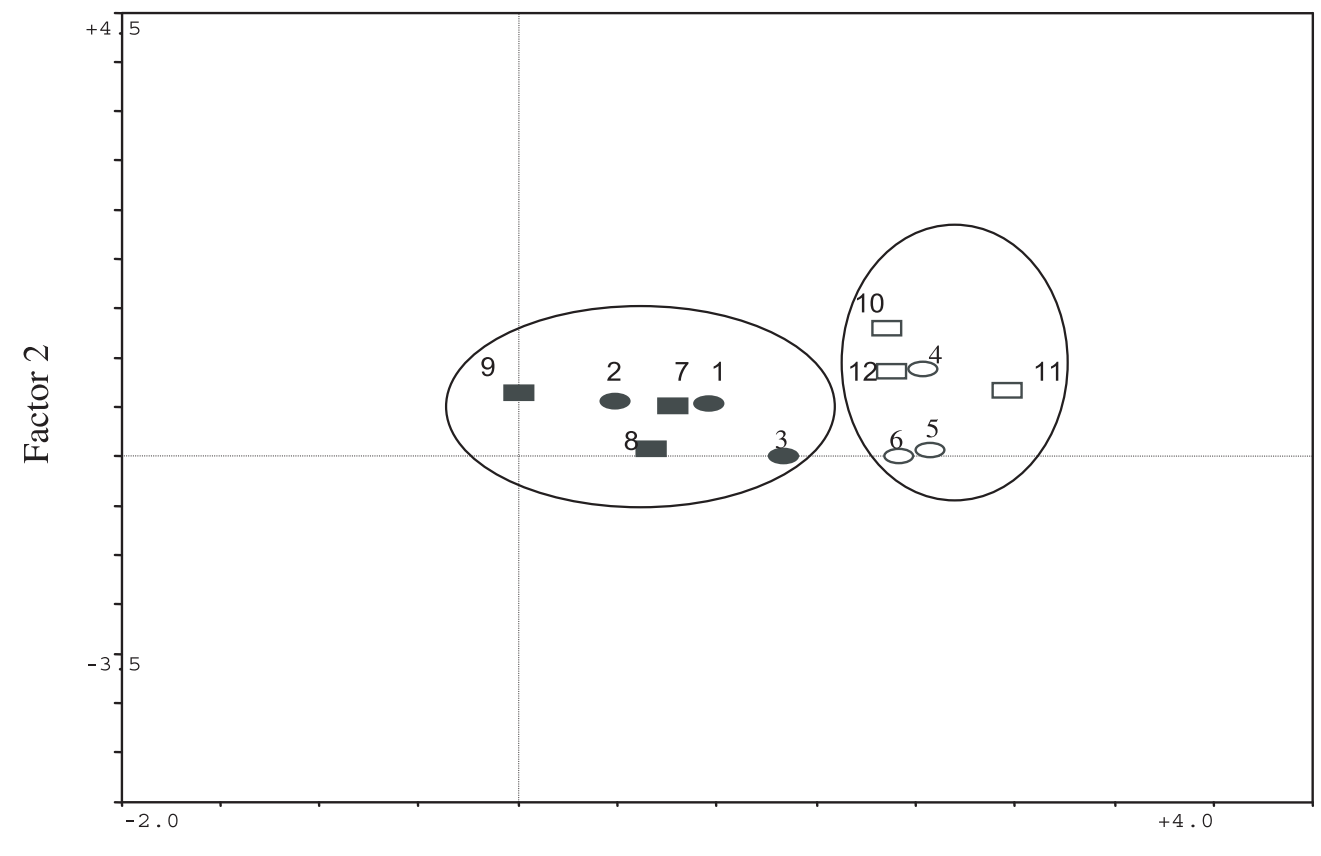

Factor 1

Figure 7. Graphic representation of the twelve vegetation plots after the Multiple Correspondence Analysis along the two main distribution axis; the most interrelated plots are shown in circles. The solid symbols are plots in shady slopes whereas the empty ones are plots in sunny slopes. Likewise, the oval symbols represent banks with micro-basins and the square ones represent banks without micro-basins.

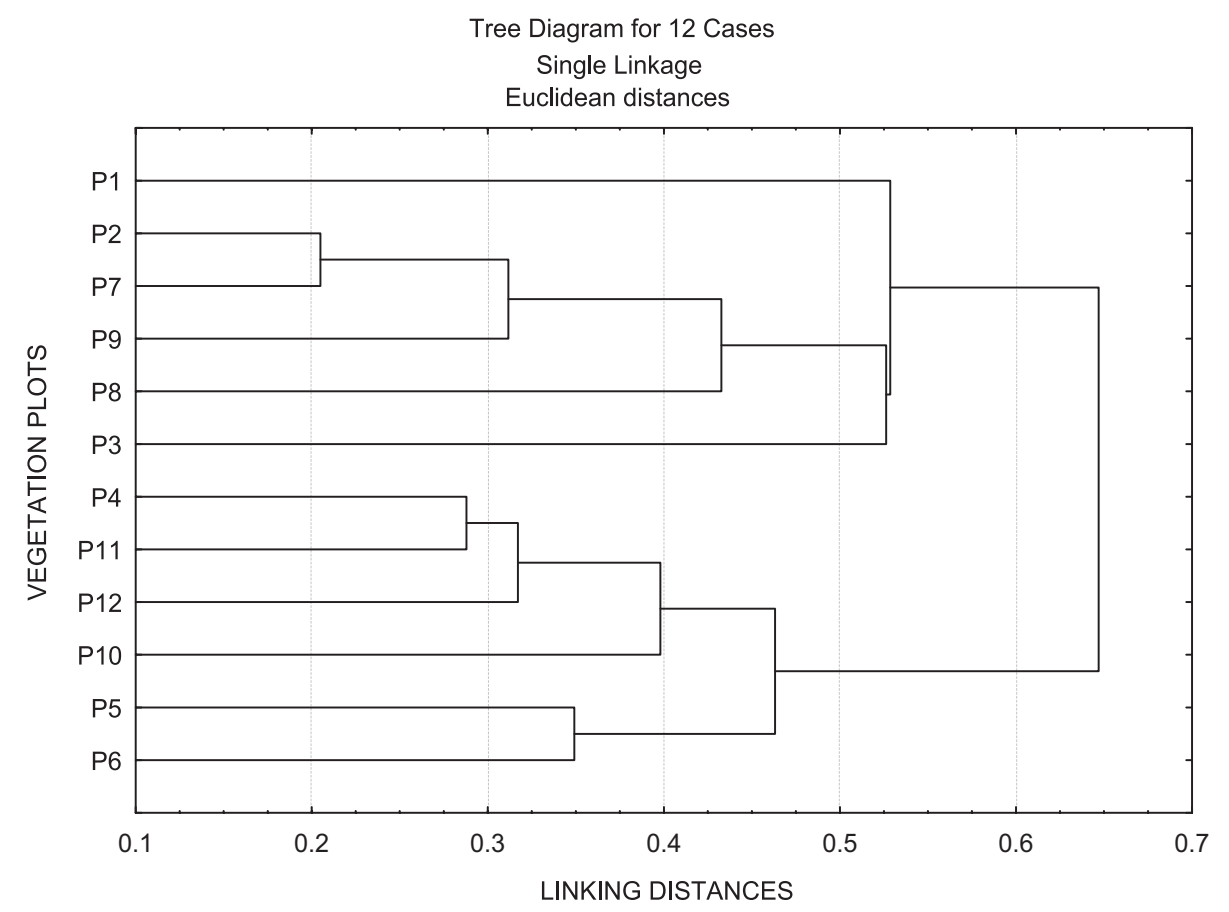

Figure 8. Hierarchical arrangement of the twelve vegetation plots studied. Within square shapes are shown the most interrelated plots. Precisely, plots P1, P2 and P3 are banks with micro-basins in shady slopes; P4, P5 and P6 are banks with micro-basins in sunny slopes; P7, P8 and P9 banks without micro-basins in shady slopes and P10, P11 and P12 are banks without micro-basins in sunny slopes. 
type of site preparation also appear in the other type. Furthermore, there are no distinguishing species in the intersection between the type of technique used and the orientation.

\section{DISCUSSION AND CONCLUSIONS}

According to the information above we can assert that when comparing growth in pairs the banks with micro-basins have clearly improved growth with regard to individuals in the same orientation planted on normal banks, that is to say, the microbasin originates an increase in soil water content $[11,24]$ in the planting area, so preventing water stress from affecting seedlings [9, 23], that generate more ecophysiology activity throughout the year [17]. Likewise, individuals on banks with micro-basins in sunny slopes have a similar or higher growth rate than those on banks without micro-basins in shady slopes, which shows a better availability of hydric resources in the micro-basins thanks to the particular type of site treatment technique focused on collecting more runoff water [31].

The main reason for the improvement of growth in microbasins is clearly better availability of water in the soil which can be used up by the plants $[9,12,30,33]$, as, even if in these cases the soil has been removed, which also improves growth, $[4,6,29]$, the volume of growth affected is the same in both cases. In the other hand, when a water constraint is imposed there is less shoot growth [15].

It is known that the improvement of the soil moisture increases Pinus halepensis Miller physiological activity and that they can be active all year around as long as they do not suffer from intense cold or drought. The individuals in worst condition are more vulnerable and their metabolic activity diminishes [16].

The strong correlation found between the annual growth in diameter of the trunk and the spring rainfall in the same year shows that spring rainfall is fundamental for the afforestation growth $[14,34]$. However, thanks to the micro-basins, which provide the plants with an additional water supply, the growth obtained is quite similar both in wet and dry springs, reason why we can conclude that there is a clear benefit and it is therefore advised to use this technique in semiarid climates such as is the one presented in our study.

Another important aspect we can highlight is that when altering microtopography to concentrate surface runoff water in the planting areas, no differences in the existing species within the different techniques studied were found. The only noticeable difference was due to the macrotopography of the area, that is, there were some differences between the plots in sunny and shady slopes but none between the plots with normal banks and the plots with banks with micro-basins. In both cases the vegetation richness was preserved despite a higher site alteration and hydrology [25]. The fact that the vegetation remains the same is important as it facilitates the seedlings growth [19], because it generate fertility islands.

From this information we can gather that soil treatment improves the growth during afforestation $[7,22,30]$ and such growth is important to protect against erosion and to reduce runoff lamination $[26,27]$ as there is an increase in the vegetable cover thanks to the planting of the pines [3, 23], without the original species having been eliminated.

When observing the vegetation inventories we can identify the main vegetable species in this area, in both orientations. Specifically, in the shade orientation the main species are Daphne gnidium L. and Lavandula lanata Boiss., whereas in the sunny slope orientation we can mainly encounter Fumana thymifolia (L.) Spach, Helianthemum almeriense Pau and Thymus membranaceus Boiss.

From this study we can gather the importance of site preparation techniques and the need of studying them in-depth, as they have shown as basic for the re-vegetation of a semiarid climate where the long drought periods are the main cause of mortality. The micro-basins system allows the new vegetation to survive and to grow better during long periods of drought, as it provides the soil with additional water supply, fundamental for the seedlings [28].

Acknowledgments: We would like to thank the material and human support received from the Centro de Investigación y Formación Agraria [Agriculture Research and Training Centre] in Granada, Spain, to the nursery centre of the Junta de Andalucía [Andalusian Regional Government] and the funding received by the ERDF (European regional Development Fund) Funds 1FD97-1117-C05-01 which have made this study possible.

\section{REFERENCES}

[1] Albaladejo J., Martínez M., Roldán A., Castillo V., Soil degradation and desertification induced by vegetation removal in a semiarid environment, Soil Use Manage. 14 (1998) 1-5.

[2] Anderson D.C., Ostler W.K., Revegetation of degraded lands at US Department of Energy and US Department of Defense Installations: Strategies and successes, Arid Soil Res. Rehab. 16 (2002) 197-212.

[3] Bellot J., Sánchez J.R., Chirino E., Hernández N., Abdelli F., Martínez J.M., Effect of different vegetation cover on the soil water balance in semiarid areas of south eastern Spain, Phys. Chem. Earth B 24 (1999) 353-357.

[4] Bocio I., de Simón E., Navarro F.B., Ripoll M.A., Efectos de diferentes procedimientos de preparación del suelo en la forestación de tierras agrarias, Actas del III Congreso Forestal Español, mesa 3, Granada, Spain, 2001, pp. 317-321.

[5] Castillo V., Martínez M., Albaladejo J., Runoff and soil loss response to vegetation removal in a semiarid environment, Soil Sci. Soc. Am. J. 61 (1997) 1116-1121.

[6] Castillo V., Querejeta J.I., Albaladejo J., Disponibilidad hídrica en repoblaciones de Pinus halepensis Mill. en medios semiáridos: efectos de los métodos de preparación del suelo, Actas del III Congreso Forestal Español, mesa 3, Granada, Spain, 2001, pp. 94-99.

[7] Cleveland B., Kjelgren R., Establishment of six tree species on deep-tilled minesoil during reclamation, For. Ecol. Manage. 68 (1994) 273-280.

[8] De Simón E., Restauración de la vegetación en cuencas mediterráneas: Repoblaciones en zonas áridas, in: ICONA (Ed.), Ecología, Madrid, Spain, 1990, pp. 401-427.

[9] De Simón E., Ripoll M.A., Bocio I., Navarro F.B., Aprovechamiento de escorrentías superficiales mediante la formación de microcuencas, en repoblaciones de zonas semiáridas, Actas del III Congreso Forestal Español, mesa 3, Granada, Spain, 2001, pp. 305-310. 
[10] Díaz E., Roldán A., Effects of reafforestation techniques on the nutrient content, photosynthetic rate and stomatal conductance of Pinus halepensis seedlings under semiarid conditions, Land Degrad. Dev. 11 (2000) 475-486.

[11] Domínguez S., Murias G., Herrero N., Peñuelas J.L., Comparación del desarrollo de ocho especies mediterráneas durante su primer año en campo y su relación con los parámetros funcionales de las plantas, Actas del III Congreso Forestal Español, mesa 3, Granada, Spain, 2001, pp. 75-81.

[12] Fernández M., Gil L., Pardos J.A., Effects of water supply on gas exchange in Pinus pinaster Ait. provenances during their first growing season, Ann. For. Sci. 57 (2000) 9-16.

[13] Fernández M., Royo A., Gil L., Pardos J.A., Effects of temperature on growth and stress hardening development of phytotron-grown seedlings of Aleppo pine (Pinus halepensis Mill.), Ann. For. Sci. 60 (2003) 277-284.

[14] Grantz D.A., Vaughn D.L., Farber R.J., Kim B., Ashbaugh L., VanCuren T., Campbell R., Bainbridge D., Zink T., Transplanting native plants to revegetate abandoned farmland in the western desert, J. Environ. Qual. 27 (1998) 960-967.

[15] Harfouche A., Retrospective early test for adult vigour of Pinus pinaster families grown under two water regimes. Implications for early selection, Ann. For. Sci. 60 (2003) 539-547.

[16] Lev-Yadum S., Wood structure and the ecology of annual growth ring formation in Pinus halepensis Miller and P. brutia, in: Ecology, Biogeography and Management of Pinus halepensis and $P$. brutia Forest Ecosystems in the Mediterranean Basin, Ne'eman \& Trabaud (Eds.), Backhuys Publishers, Leiden 2000, pp. 67-78.

[17] Liphschitz N., Lev-Yadun S., Rosen E., Waisel Y., The annual rhythm of activity of the lateral meristems (cambium and phellogen) in Pinus halepensis Mill. and Pinus pinea L., IAWA Bull. 5, 1984.

[18] López J.A., Martínez J.J., Orozco E., Ferrándis P., Selva M., Evaluación de técnicas de forestación con encinas y arbusto en terrenos agrícolas de la Mancha, España, Actas del III Congreso Forestal Español, mesa 3, Granada, Spain, 2001, pp. 143-149.

[19] Lloret F., Fire, canopy and seedling dynamics in Mediterranean shrubland of northeastern Spain, J. Veg. Sci. 9 (1998) 417-430.

[20] Lloret F., Casanovas C., Peñuelas J., Seedling survival of Mediterranean species in relation to root: shoot ratio, seed size and water and nitrogen use, Funct. Ecol. 13 (1999) 210-216.

[21] Martínez M., Castillo V., Albaladejo J., Hydrological and erosional response to natural rainfall in a semiarid area of south-east Spain, Hydrol. Process. 15 (2001) 557-571.

[22] Martínez J.F., González G., Alvarez J., Bago D., Castillo V., Crecimiento en repoblaciones de Pinus halepensis Mill. en medios semiáridos: el efecto de los tratamientos de suelo y planta está influido por la variabilidad ambiental, Actas del III Congreso Forestal Español, mesa 3, Granada, Spain, 2001, pp. 255-262.
[23] Martínez de Azagra A., Mongil J., Algunos criterios para el diseño de sistemas de recolección de agua en repoblaciones forestales Actas del III Congreso Forestal Español, mesa 3, Granada, Spain, 2001, pp. 272-277.

[24] Martínez de Azagra A., Diseño de sistemas de recolección de agua para la repoblación forestall, Mundi-Prensa (Ed.), Madrid, Spain, 1996.

[25] Navarro F.B., Ripoll M.A., Bocio I., de Simón E., Importancia de la vegetación natural en la forestación de tierras agrarias de zonas semiáridas: respuesta a los procedimientos de preparación del suelo, Actas del III Congreso Forestal Español, mesa 3, Granada, Spain, 2001, pp. 292-297.

[26] Olarieta J.R., Usón A., Rodríguez R., Rosa M., Blanco R., Antúnez M., Land requirements for Pinus halepensis Mill. growth in a plantation in Huesca, Spain, Soil Use Manage. 16 (2000) 88-92.

[27] Querejeta J.I., Roldán A., Albaladejo J., Castillo V., The role of mycorrhizae, site preparation, and organic amendment in the afforestation of a semiarid Mediterranean site with Pinus halepensis, For. Sci. 44 (1998) 203-211.

[28] Rey J.M., Growth and survival in Quercus ilex L. seedlings after irrigation and artificial shading on Mediterranean set-aside agricultural land, Ann. Sci. For. 55 (1998) 801-807.

[29] Roldán A., Querejeta I., Albaladejo J., Castillo V., Survival and growth of Pinus halepensis Miller seedlings in a semiarid environment after forest soil transfer, terracing and organic amendments, Ann. Sci. For. 53 (1996) 1099-1112.

[30] Ruiz F., Soria F., Toval G., Ensayos de preparación del terreno para el establecimiento de masas clonales de Eucalyptus globulus (Labill.) en distintos suelos de la provincia de Huelva, Actas del III Congreso Forestal Español, mesa 3, Granada, Spain, 2001, pp. 117-124.

[31] Stone J.E., Kolb T.E., Covington W.W., Effects of restoration thinning on presettlement Pinus ponderosa in northern Arizona, Restor. Ecol. 7 (1999) 172-182.

[32] South D.B., Rose R.W., McNabb K.L., Nursery and site preparation interaction research in the United States, New For. 22 (2001) 43-58.

[33] South D.B., Zwolinski J.B., Kotze H., Early growth responses from weed control and planting larger stock of Pinus radiata are greater than that obtained from mechanical soil cultivation, New For. 22 (2001) 199-211.

[34] Villar P., Ocaña L., Peñuelas J., Carrasco I., Effect of water stress conditioning on the water relations, root growth capacity, and the nitrogen and non-structural carbohydrate concentration of Pinus halepensis Mill. (Aleppo pine) seedlings, Ann. For. Sci. 56 (1999) 459-465.

[35] Zamora R., Gómez L., Castro J., Hójar J.A., Gómez J.M., Elola S., Montes J., Los matorrales facilitan la supervivencia de los brinzales en el monte mediterráneo: evaluación de una nueva técnica de repoblación forestall, Actas del III Congreso Forestal Español, mesa 3, Granada, Spain, 2001, pp. 154-159. 